Article

\title{
Synthesis, Characterization and in Vitro Antitumor Activity of Platinum(II) Oxalato Complexes Involving 7-Azaindole Derivatives as Coligands
}

\section{Pavel Štarha ${ }^{1}$, Zdeněk Trávníček $^{1{ }^{1} *}$, Igor Popa ${ }^{1}$ and Zdeněk Dvořák ${ }^{2}$}

1 Regional Centre of Advanced Technologies and Materials, Department of Inorganic Chemistry, Faculty of Science, Palacký University, 17. listopadu 12, CZ 77146 Olomouc, Czech Republic; E-Mails: pavel.starha@upol.cz (P.S.); igor.popa@upol.cz (I.P.)

2 Regional Centre of Advanced Technologies and Materials, Department of Cell Biology and Genetics, Faculty of Science, Palacký University, Šlechtitelů 11, CZ 78371 Olomouc, Czech Republic; E-Mail: zdenek.dvorak@upol.cz

* Author to whom correspondence should be addressed; E-Mail: zdenek.travnicek@upol.cz; Tel.: +420-585-634-352; Fax: +420-585-634-954.

Received: 7 July 2014; in revised form: 16 July 2014 / Accepted: 17 July 2014 /

Published: 25 July 2014

\begin{abstract}
The platinum(II) oxalato complexes [Pt(ox)(naza) $)_{2}$ (1-3) were synthesized and characterized by elemental analysis $(\mathrm{C}, \mathrm{H}, \mathrm{N})$, multinuclear NMR spectroscopy $\left({ }^{1} \mathrm{H},{ }^{13} \mathrm{C}\right.$, ${ }^{15} \mathrm{~N},{ }^{195} \mathrm{Pt}$ ) and electrospray ionization mass spectrometry (ESI-MS); naza = 4-chloro-7azaindole (4Claza; 1), 3-bromo-7-azaindole (3Braza; 2) or 4-bromo-7-azaindole (4Braza; 3). The prepared substances were screened for their in vitro antitumor activity on the osteosarcoma (HOS) and breast adenocarcinoma (MCF7) human cancer cell lines, where 2 showed moderate antitumor effect $\left(\mathrm{IC}_{50}=27.5 \mu \mathrm{M}\right.$, and $18.3 \mu \mathrm{M}$, respectively). The complex 2 was further tested on a panel of six others human cancer cell lines, including the malignant melanoma (G361), cervix carcinoma (HeLa), ovarian carcinoma (A2780), cisplatin-resistant ovarian carcinoma (A2780R), lung carcinoma (A549) and prostate adenocarcinoma (LNCaP). This substance was found to be moderate antitumor effective against $\mathrm{G} 361\left(\mathrm{IC}_{50}=17.3 \mu \mathrm{M}\right), \mathrm{HeLa}\left(\mathrm{IC}_{50}=31.8 \mu \mathrm{M}\right)$ and $\mathrm{A} 2780\left(\mathrm{IC}_{50}=19.2 \mu \mathrm{M}\right)$ cell lines. The complex 2 was also studied by NMR for its solution stability and by ESI-MS experiments for its ability to interact with biomolecules, such as cysteine, glutathione or guanosine 5'-monophosphate.
\end{abstract}


Keywords: platinum(II) complexes; oxalato complexes; 7-azaindole derivatives; multinuclear NMR; antitumor activity

\section{Introduction}

Platinum carboxylates represent a notable group of transition metal complexes, which have been used for the treatment of various types of cancer for many years [1-3]. Various carboxylate anions involved in the structures of the clinically used or studied platinum-based metallotherapeutics can be mentioned, particularly the cyclobutane-1,1-dicarboxylate dianion (involved in carboplatin), glycolate dianion (involved in nedaplatin), lactate dianion (involved in lobaplatin), malonate dianion (involved in heptaplatin), acetate anion (involved in satraplatin) or neodecanoate anion (involved in aroplatin) [4-9]. One of the carboxylate-based leaving groups is the oxalate dianion involved in the well-known substance oxaliplatin clinically used mainly for the treatment of colorectal tumours [10]. In other words, the platinum(II) oxalato complexes are, thanks to the mentioned oxaliplatin, biologically relevant and worth studying group of compounds.

Search for novel antitumor active platinum complexes in terms of novel carrier (i.e., $N$-donor ligands) and leaving (i.e., carboxylates) ligands is one of the crucial challenge of modern bioinorganic chemistry [11-13], although those involved in clinically used drugs are still substantial part of this research, as exemplified by the $\mathrm{NH}_{3}$ carrier ligands involved in original platinum-based drug cisplatin, as well as in currently studied picoplatin [14]. As for the biologically effective platinum oxalato complexes, it is quite interesting that although these complexes can be considered, thanks to clinically used anticancer drug oxaliplatin [15], as biologically perspective group of compounds [16], not many papers dealing with such compounds in connection with their biological effect have been reported in last five years [17-24]. Our research group reported the platinum(II) oxalato complexes involving variously substituted N6-benzyladenine derivatives [17-19], whose the most effective representatives showed $\mathrm{IC}_{50}(\mathrm{HOS})=3.6 \mu \mathrm{M}\left(\left[\mathrm{Pt}(\mathrm{ox})\left(\mathrm{L}_{1}\right)\right] ; \mathrm{L}_{1}=2\right.$-chloro-N6-(2-methoxybenzyl)-9-isopropyladenine $)$ and $\mathrm{IC}_{50}(\mathrm{MCF} 7)=3.6 \mu \mathrm{M}\left(\left[\mathrm{Pt}(\mathrm{ox})\left(\mathrm{L}_{2}\right)\right] ; \mathrm{L}_{2}=2\right.$-chloro-N6-(2,4-dimethoxybenzyl)-9-isopropyladenine). Utku et al. described the platinum(II) oxalato complexes with 2-phenylbenzimidazole ligand and their antibacterial and antifungal activity [20]. The work of Silva et al. dealt with the $\left[\mathrm{Pt}(\mathrm{ox})\left(\mathrm{L}_{3}\right)\right]\left(\mathrm{L}_{3}\right.$ symbolizes a long-chain aliphatic diamine) and their cytotoxic effect against A549, B16-F1, B16-F10 and MDA-MB-231 cancer cells and BHK-21 and CHO non-cancer cells. The obtained results proved four reported oxalato complexes as less active against the named cancer cells $\left(\mathrm{IC}_{50}(\mathrm{~A} 549)=12.6-60.6 \mu \mathrm{M}\right.$, $\left.\mathrm{IC}_{50}(\mathrm{~B} 16-\mathrm{F} 1)=14.5-21.9 \mu \mathrm{M}, \mathrm{IC}_{50}(\mathrm{~B} 16-\mathrm{F} 10)=16.6-38.0 \mu \mathrm{M}, \mathrm{IC}_{50}(\mathrm{MDA}-\mathrm{MB}-231)=16.6-25.1 \mu \mathrm{M}\right)$ as compared with cisplatin $\left(\mathrm{IC}_{50}(\mathrm{~A} 549)=2.7 \mu \mathrm{M}, \mathrm{IC}_{50}(\mathrm{~B} 16-\mathrm{F} 1)=3.5 \mu \mathrm{M}, \mathrm{IC}_{50}(\mathrm{~B} 16-\mathrm{F} 10)=4.2 \mu \mathrm{M}\right.$, $\left.\mathrm{IC}_{50}(\mathrm{MDA}-\mathrm{MB}-231)=1.4 \mu \mathrm{M}\right)$ [21]. Other platinum(II) oxalato complexes involved 1,2diaminocyclohexane with variously monoalkyl-substituted nitrogen atom $\left(\mathrm{L}_{4}\right)$ [22]. These substances were studied for their in vitro cytotoxicity against HepG-2, MCF7, A549 and HCT-116 human cancer cell lines. The antitumor effect of the most effective complex, expressed as $\mathrm{IC}_{50}=3.7,8.8,18.4$, and $2.1 \mu \mathrm{M}$, respectively, against the mentioned cells, exceed both cisplatin and oxaliplatin used as standards in this study. The biological perspective of the oxalate anion, used as $O$-donor ligand in the 
biologically active transition metal complexes, can be also demonstrated on the palladium(II) oxalato complexes with $N 6$-benzyladenin-based $N$-donor ligands, which in many cases showed noticeable antitumor activity against human cancer cell lines in many cases $[19,25,26]$.

The herein described platinum(II) oxalato complexes with variously substituted 7-azaindole halogeno-derivatives (1-3; Scheme 1), namely 4-chloro-7-azaindole (4Claza; the complex 1), 3-bromo-7-azaindole (3Braza; the complex 2) and 4-bromo-7-azaindole (4Braza; the complex 3), follow recently reported analogues involving differently substituted 7-azaindoles (3-chloro-7-azaindole, 3Claza; 3-iodo-7-azaindole, 3Iaza; 5-bromo-7-azaindole, 5Braza) [24]. Although the mentioned recently reported platinum(II) oxalato complexes with $3 \mathrm{Claza}$, 3Iaza and $5 \mathrm{Braza} \mathrm{N}$-donor ligands did not show any biological effect on osteosarcoma HOS, breast carcinoma MCF7 and prostate carcinoma LNCaP human cancer cell lines (these complexes were poorly soluble in the medium used), we decided to study, whether substitution variability of the 7-azaindole moiety within the platinum(II) oxalato complexes may led to the formation of antitumor active compounds.

Scheme 1. The synthesis and schematic representation of the prepared $\left[\operatorname{Pt}(\mathrm{ox})(\text { naza })_{2}\right]$ complexes (1-3) given with the atom numbering scheme of the used 7-azaindole derivatives.

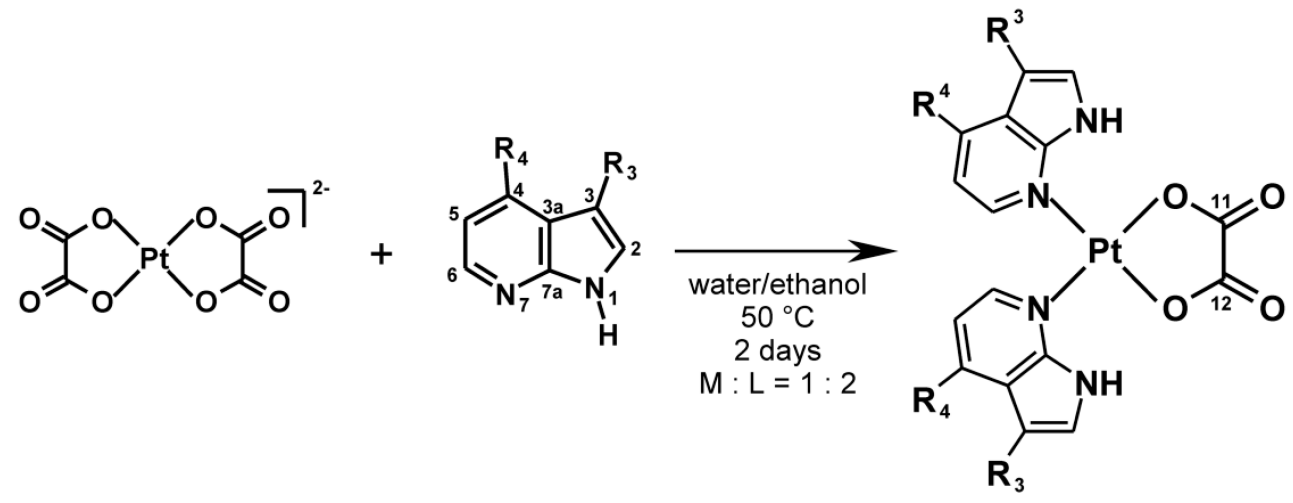

$\mathrm{R}_{3}=\mathrm{H}$ and $\mathrm{R}_{4}=\mathrm{Cl}$ for 4 Claza and [Pt(ox)(4Claza) $\left.)_{2}\right](\mathbf{1}) ; \mathrm{R}_{3}=\mathrm{Br}$ and $\mathrm{R}_{4}=\mathrm{H}$ for $3 B r a z a$ and [Pt(ox)(3Braza) $)_{2}$ (2) and $\mathrm{R}_{3}=\mathrm{H}$ and $\mathrm{R}_{4}=\mathrm{Br}$ for $4 B$ raza and [Pt(ox)(4Braza) $)_{2}$ (3).

\section{Results and Discussion}

\subsection{General Properties}

The platinum(II) oxalato complexes $\left[\mathrm{Pt}(\mathrm{ox})(\text { naza })_{2}\right](\mathbf{1}-\mathbf{3}$; Scheme 1) were prepared by a one-step synthetic procedure using the bis(oxalato)platinate(II) salt as a starting compound [17]. The composition of the products was proved by the results of elemental analysis. The electrospray ionization mass spectra obtained in the positive mode (ESI+) of the studied complexes contained the molecular peaks detected at $589.2 \mathrm{~m} / \mathrm{z}$ (calc. 589.0; 5\%; $\left\{\left[\mathrm{Pt}(\mathrm{ox})(4 \mathrm{Claza})_{2}\right]+\mathrm{H}\right\}^{+}$for 1), $678.9 \mathrm{~m} / \mathrm{z}$ (calc. 678.9; 40\%; $\left\{\left[\mathrm{Pt}(\mathrm{ox})(3 \mathrm{Braza})_{2}\right]+\mathrm{H}\right\}^{+}$for 2$)$ and $679.0 \mathrm{~m} / \mathrm{z}$ (calc. $678.9 ; 25 \%$; $\left\{\left[\mathrm{Pt}(\mathrm{ox})(4 \mathrm{Braza})_{2}\right]+\mathrm{H}\right\}^{+}$ for 3), their adducts with different cations, namely $627.1 \mathrm{~m} / \mathrm{z}$ (calc. $626.9 ; 30 \% ;\left\{\left[\mathrm{Pt}(\mathrm{ox})(4 \mathrm{Claza})_{2}\right]+\mathrm{K}\right\}^{+}$ for 1), $611.1 \mathrm{~m} / \mathrm{z}$ (calc. 611.0; 50\%; $\left\{\left[\mathrm{Pt}(\mathrm{ox})(4 \mathrm{Claza})_{2}\right]+\mathrm{Na}\right\}^{+}$for 1), $716.9 \mathrm{~m} / \mathrm{z}$ (calc. 716.8; 100\%; $\left\{\left[\mathrm{Pt}(\text { ox })(3 \mathrm{Braza})_{2}\right]+\mathrm{K}\right\}^{+}$for 2$), 701.0 \mathrm{~m} / \mathrm{z}$ (calc. 700.9; 15\%; $\left\{\left[\mathrm{Pt}(\mathrm{ox})(3 \mathrm{Braza})_{2}\right]+\mathrm{Na}\right\}^{+}$for 2), $716.9 \mathrm{~m} / \mathrm{z}$ (calc. 716.8; 100\%; $\left\{\left[\mathrm{Pt}(\mathrm{ox})(4 \mathrm{Braza})_{2}\right]+\mathrm{K}\right\}^{+}$for 3$)$ and $701.1 \mathrm{~m} / \mathrm{z}$ (calc. 700.9; 55\%; $\left\{\left[\mathrm{Pt}(\mathrm{ox})(4 \mathrm{Braza})_{2}\right]+\mathrm{Na}\right\}^{+}$ for 3). The peak of the released $N$-donor ligand was found at $153.1 \mathrm{~m} / \mathrm{z}$ (calc. $153.0 ; 5 \% ;\{4 \mathrm{Claza}+\mathrm{H}\}^{+}$ 
for 1), $197.0 \mathrm{~m} / \mathrm{z}$ (calc. 197.0; 20\%; $\{3 \mathrm{Braza}+\mathrm{H}\}^{+}$for 2) and $197.1 \mathrm{~m} / \mathrm{z}$ (calc. 197.0; 15\%; $\{4 \mathrm{Braza}+\mathrm{H}\}^{+}$for 3$)$. The pseudomolecular peaks of the $\left\{\left[\mathrm{Pt}(\mathrm{ox})(\text { naza })_{2}\right]-\mathrm{H}\right\}^{-}$species were detected by means of ESI- (electrospray ionization in the negative mode) mass spectrometry at $585.9 \mathrm{~m} / \mathrm{z}$ (calc. 586.0; 60\%; $\left\{\left[\mathrm{Pt}(\mathrm{ox})(4 \mathrm{Claza})_{2}\right]-\mathrm{H}\right\}^{-}$for 1) and $676.0 \mathrm{~m} / \mathrm{z}$ (isomeric complexes 2 and 3; calc. 675.9; 100\%; $\left\{\left[\mathrm{Pt}(\mathrm{ox})(3 \mathrm{Braza})_{2}\right]-\mathrm{H}\right\}^{-}$for 2, and: calc. 675.9; 85\%; $\left\{\left[\mathrm{Pt}(\mathrm{ox})(4 \mathrm{Braza})_{2}\right]-\mathrm{H}\right\}^{-}$for 3). The ESImass spectra of the studied compounds also contain the peaks whose mass correspond to the $\{[\operatorname{Pt}(\text { ox })(\text { naza })]-\mathrm{H}\}^{-}$fragment $\left(434.0 \mathrm{~m} / \mathrm{z}\right.$, calc. 434.0; 30\%; $\{[\mathrm{Pt}(\mathrm{ox})(4 \mathrm{Claza})]-\mathrm{H}\}^{-}$for $1 ; 478.1 \mathrm{~m} / \mathrm{z}$, calc. $477.9 ; 30 \%$; $\{[\mathrm{Pt}(\mathrm{ox})(3 \mathrm{Braza})]-\mathrm{H}\}^{-}$for $2 ; 478.1 \mathrm{~m} / \mathrm{z}$, calc. $477.9 ; 65 \% ;\{[\mathrm{Pt}(\mathrm{ox})(4 \mathrm{Braza})]-\mathrm{H}\}^{-}$ for 3) and $\{\text { naza }-\mathrm{H}\}^{-}$ligand $\left(151.0 \mathrm{~m} / \mathrm{z}\right.$, calc. $151.0 ; 10 \% ;\{4 C l a z a-H\}^{-}$for $1 ; 195.1 \mathrm{~m} / \mathrm{z}$, calc. 195.0; $15 \% ;\{3 B r a z a-H\}^{-}$for $3 ; 195.1 \mathrm{~m} / z$, calc. $195.0 ; 20 \% ;\{4 B r a z a-H\}^{-}$for 3$)$.

The complexes 1-3, as well as the starting compounds $n$ aza and $\mathrm{K}_{2}\left[\mathrm{Pt}(\mathrm{ox})_{2}\right] \cdot 2 \mathrm{H}_{2} \mathrm{O}$, were studied by means of multinuclear and 2D NMR spectroscopy. All the ${ }^{1} \mathrm{H},{ }^{13} \mathrm{C}$ and ${ }^{15} \mathrm{~N}$ signals of free naza molecules were unambiguously detected in the spectra of corresponding platinum(II) complexes and assigned by means of the below-mentioned 2D NMR experiments. The significantly different ${ }^{15} \mathrm{~N}-\mathrm{NMR}$ coordination shift values of the $\mathrm{N} 1(|\Delta \delta|=2.5-3.4 \mathrm{ppm})$ and $\mathrm{N} 7(|\Delta \delta|=114.0-115.1 \mathrm{ppm})$ atoms clearly proved the coordination of naza molecules through the $\mathrm{N} 7$ atoms. The ${ }^{13} \mathrm{C}-\mathrm{NMR}$ chemical shifts of the $\mathrm{C} 11$ and $\mathrm{C} 12$ atoms of the oxalate dianion (detected at 165.9-166.0 ppm) and the ${ }^{195} \mathrm{Pt}$ chemical shifts, which equal -1770.1 (1), -1783.5 (2) and -1772.5 (3), correlate well with the values of the formerly reported platinum(II) oxalato complexes with 7-azaindole [23] or its derivatives [24].

\subsection{NMR and ESI-MS Stability and Interaction Studies}

${ }^{1} \mathrm{H}$ and ${ }^{195} \mathrm{Pt}$ NMR spectroscopy (solution of 2 in DMF- $d_{7}$ and DMF- $d_{7} / \mathrm{H}_{2} \mathrm{O}$ mixture, 9:1 $v / v$ ) and electrospray ionization mass spectrometry (ESI-MS; solution of $\mathbf{2}$ in methanol and water/methanol mixture, $1: 1 \mathrm{v} / \mathrm{v}$ ) (the presence of the organic solvents ensured the solubility of the studied complex, because carrying out of the experiments in water was prevented by limited solubility of the mentioned complex in water) were used to investigate the behaviour of the representative complex 2 in the mentioned organic or water-containing solvents. As it is generally accepted for the antitumor active platinum(II) complexes, hydrolysis is a crucial step within the mechanism of action, which lead to the replacement of leaving groups (i.e., the oxalato ligands) and formation of the activated and more reactive aqua- and/or hydroxidoplatinum(II) species, probably with formulas cis-[ $\left.\mathrm{Pt}\left(\mathrm{H}_{2} \mathrm{O}\right)_{2}(3 \mathrm{Braza})_{2}\right]^{2+}$ and/or cis- $\left[\mathrm{Pt}(\mathrm{OH})_{2}(3 \mathrm{Braza})_{2}\right]$ in our case $[1,2,27,28]$. The hydrolysis of the platinum(II) oxalate complexes should be connected with opening of the $\mathrm{PtO}_{2} \mathrm{C}_{2}$ ring and/or substitution of the oxalate dianion by two $\mathrm{H}_{2} \mathrm{O}$ or $\mathrm{OH}^{-}$species as ligands, both resulting in the change of inner coordination sphere (resulting in new peaks in mass spectra) and electron density within the initial complex, which is known to provide different ${ }^{1} \mathrm{H}$ and ${ }^{195} \mathrm{Pt}$ NMR chemical shifts [27,28]. Since we did not observe any new signals in both the ${ }^{1} \mathrm{H}$ and ${ }^{195} \mathrm{Pt}$ NMR spectra (Figure 1), it can be concluded that the complex 2 is stable and do not undergo any changes within the structure during 5 days in DMF- $d_{7}$ as well as in the DMF $-d_{7} / \mathrm{H}_{2} \mathrm{O}$ mixture. Similarly it was found that the complex is stable and did not show any change in the composition from the mass spectrometry point of view, because its mass spectra (methanol solutions) recorded after $12 \mathrm{~h}$ did not contain any novel peaks as compared with the spectra obtained on the fresh solution of 2 . 
Figure 1. Time dependent ${ }^{195} \mathrm{Pt}$ NMR spectra on the representative complex 2 dissolved in DMF- $d_{7} / \mathrm{H}_{2} \mathrm{O}$ mixture $(9: 1 v / v)$ showing on the stability of the complex.

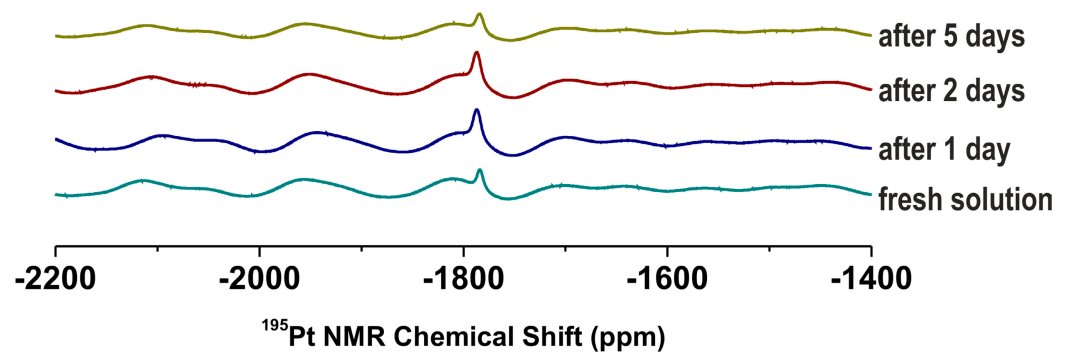

In the case of water/methanol mixture solution of $\mathbf{2}$, we detected several new peaks in the mass spectra in comparison with the spectra of $\mathbf{2}$ dissolved in pure methanol, but their isotopic distribution did not correspond to that of platinum-containing species (Figure 2). In other words, no new platinumcontaining species was found in the mass spectra recorded on the water/methanol solution of $\mathbf{2}$, which, as in the case of NMR, proved that no hydrolytic processes proceeded under the experimental condition used. Thus it can be said that we did not get any evidence of the hydrolysis usually involved within the mechanism of action of the cytotoxic active platinum(II) complexes including the clinically used platinum(II) oxalate complex oxaliplatin [1,2,29]. On the other hand, it is known that the oxaliplatin hydrolysis in water (leading to diaqua-species) and under in vivo conditions has different course, since the latter one provides the carbonato or phosphato adducts (instead of the above mentioned diaqua ones), which consequently enhance the reactivity of such species towards nucleophiles including nucleobases [30-32]. It means that although we did not observed any processes usually associated with the action of cytotoxic platinum(II) complexes (see Section 2.3. for the in vitro cytotoxicity of 1-3) under experimental conditions, the cytotoxic action itself is not excluded with respect to different conditions in the cells (cytosol involving various ions) as compared with those used in the herein discussed NMR and ESI-MS experiments.

ESI-MS was also used to study the ability of $\mathbf{2}$ to interact with sulphur-containing biomolecules (cysteine (cys) and reduced glutathione (GSH)) or guanosine 5'-monophosphate (GMP) in water/methanol mixture $(1: 1 \mathrm{v} / \mathrm{v})$ (again, the presence of the organic solvent ensured the solubility of the studied complex). It is well-known that ability of the cytotoxic platinum(II) complexes to interact with the intracellular sulphur-containing compounds correlates with their activity as well as with the resistance of the respective tumours in terms of inactivation of the platinum(II) species and their removing from the cell $[1,29]$. With respect to this phenomena, ability of the studied platinum(II) complexes to interact with the sulphur-containing biomolecules should be investigated by relevant techniques. In the case of this work, we studied an interaction of $\mathbf{2}$ with the mixture of cys and GSH in water/methanol mixture. We did not observe any adducts of $\mathbf{2}$ (or its fragments formed during ionization) with cysteine or reduced glutathione assignable to the species formed by their interaction (Figure 2), which corresponds to the above-described reluctance of $\mathbf{2}$ to undergo hydrolysis. The only exception from this statement is very weak peak of the $\left\{\left[\mathrm{Pt}(\mathrm{cys})(\mathrm{ox})(3 \mathrm{Braza})_{2}\right]+\mathrm{H}\right\}^{+}$species (Figure 2, inset) detected in the ESI+ spectra of the studied complex 2 at $799.5 \mathrm{~m} / \mathrm{z}$ (calcd. $799.9 \mathrm{~m} / \mathrm{z}$ ), which most probably contains a ring-opened product of the interaction with a monodentate bound oxalate dianion. 
Figure 2. The ESI+ mass spectra (recorded on fresh solutions and after $12 \mathrm{~h}$ ) for the stability in methanol/water mixture, and for the interaction of the representative complex 2 with the mixture of cysteine and reduced glutathione (cys+GSH), and guanosine 5'-monophosphate (GMP), given together with the spectra of the fresh solutions of the individual reactants, i.e., the complex 2, cys $+\mathrm{GSH}$ mixture and GMP.

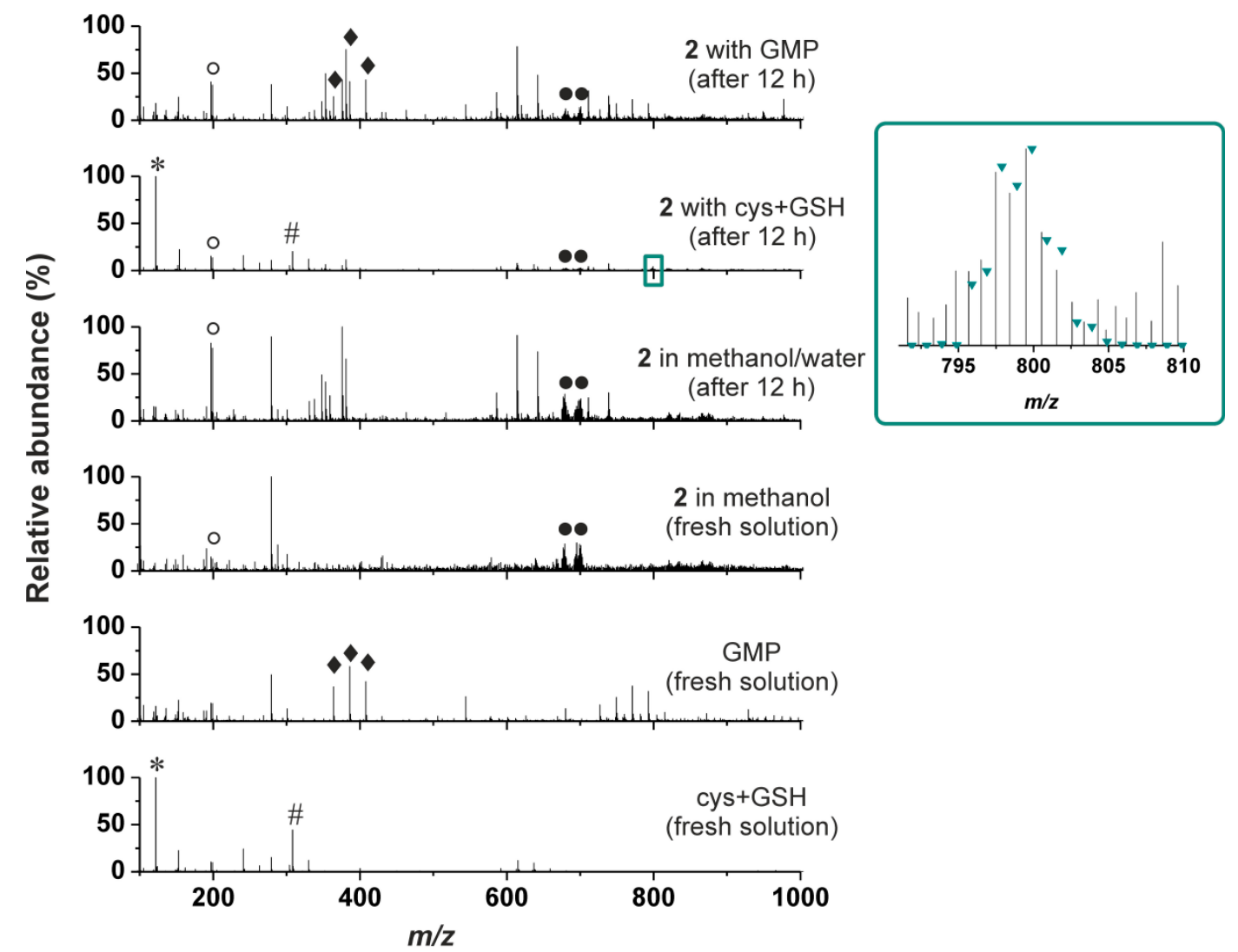

* stands for $\{\text { cys }+\mathrm{H}\}^{+}, \#$ for $\{\mathrm{GSH}+\mathrm{H}\}^{+}$, for $\left\{\mathrm{H}_{2} \mathrm{GMP}+\mathrm{H}\right\}^{+},\{\mathrm{HNaGMP}+\mathrm{H}\}^{+}$and $\left\{\mathrm{Na}_{2} \mathrm{GMP}+\mathrm{H}\right\}^{+}$, $\circ$ for $\{3 B r a z a+H\}^{+}$and $\bullet$ for $\left\{\left[\mathrm{Pt}(\text { ox })(3 B r a z a)_{2}\right]+\mathrm{H}\right\}^{+}$and $\left\{\left[\mathrm{Pt}(\text { ox })(3 B r a z a)_{2}\right]+\mathrm{Na}\right\}^{+}$; Inset: Part of the ESI+ mass spectrum of the mixture of the complex 2 with cys $+\mathrm{GSH}$ (recorded $12 \mathrm{~h}$ after the preparation) showing the peak of the $\left\{\left[\mathrm{Pt}(\mathrm{cys})(\mathrm{ox})(3 \mathrm{Braza})_{2}\right]+\mathrm{H}\right\}^{+}$species, together with the simulated isotopic distribution labeled as the green triangles.

The mechanism of action itself of the clinically used antitumor active platinum(II) complexes is based on the covalent binding of activated platinum(II) species to the nuclear DNA molecule of the tumour cells [33], which is also expected for most of the platinum(II) complexes having cytotoxic effect. A simple model to study the ability of the platinum(II) complexes to bind DNA molecule is based on binding reactions with various nucleobase-based compounds such as GMP employed in this work. However, we have to state that we did not detect any species whose mass and isotopic distribution would correspond with those of adduct of the studied complex, its fragments or its hydrolysis products with GMP (Figure 2).

\subsection{In Vitro Cytotoxicity}

The complexes 1-3 were screened for their in vitro antitumor activity against two types of the human cancer cell lines - osteosarcoma (HOS) and breast adenocarcinoma (MCF7) (Table 1). In the 
case of $\mathbf{1}$ and $\mathbf{3}$, the testing was limited by low solubility of the compounds, which can be expressed as $<1.0 \mu \mathrm{M}$. Interestingly, the solubility of 2 was much higher $(>50.0 \mu \mathrm{M})$ in the medium used. This compound showed the moderate in vitro anticancer activity, concretely $27.5 \pm 3.4 \mu \mathrm{M}$ against HOS and $18.3 \pm 3.6 \mu \mathrm{M}$ against MCF7 cells, which is comparable effect with that of cisplatin $\left(\mathrm{IC}_{50}(\mathrm{HOS})=\right.$ $\left.25.4 \pm 8.5 \mu \mathrm{M}, \mathrm{IC}_{50}(\mathrm{MCF} 7)=18.1 \pm 5.1 \mu \mathrm{M}\right)($ Table 1, Figure 3). It has to be mentioned, that we also tried to compare the results of $\mathbf{2}$ with another platinum-based drug, oxaliplatin, which involve the same living group in its structure as the studied complexes 1-3. However, such comparison is limited by the fact that oxaliplatin did not show any cytotoxic effect on both cell lines up to the $50.0 \mu \mathrm{M}$ concentration $\left(\mathrm{IC}_{50}(\mathrm{HOS})>50.0 \mu \mathrm{M}, \mathrm{IC}_{50}(\mathrm{MCF} 7)>50.0 \mu \mathrm{M}\right)$. Nevertheless, it can be stated that the complex 2 exceeded the in vitro antitumor activity of oxaliplatin on HOS and MCF7 human cancer cell lines.

Table 1. The results of the in vitro antitumor activity of the studied platinum(II) oxalato complexes (1-3), cisplatin (CDDP) and oxaliplatin (OXA) against osteosarcoma (HOS), breast adenocarcinoma (MCF7), malignant melanoma (G361), cervix carcinoma (HeLa), ovarian carcinoma (A2780), cisplatin-resistant ovarian carcinoma (A2780R), lung carcinoma (A549) and prostate carcinoma (LNCaP) human cancer cell lines, as obtained by an MTT assay on the cells exposed to the compounds for $24 \mathrm{~h}$.

\begin{tabular}{ccccccccc}
\hline & HOS & MCF7 & G361 & HeLa & A2780 & A2780R & A549 & LNCaP \\
\hline $\mathbf{1}$ & $>1.0$ & $>1.0$ & $\mathrm{nt}$ & $\mathrm{nt}$ & $\mathrm{nt}$ & $\mathrm{nt}$ & $\mathrm{nt}$ & $\mathrm{nt}$ \\
$\mathbf{2}$ & $27.5 \pm 3.4$ & $18.3 \pm 3.6$ & $17.3 \pm 3.1$ & $31.8 \pm 6.2$ & $19.2 \pm 3.7$ & $>50.0$ & $>50.0$ & $>50.0$ \\
$\mathbf{3}$ & $>1.0$ & $>1.0$ & $\mathrm{nt}$ & $\mathrm{nt}$ & $\mathrm{nt}$ & $\mathrm{nt}$ & $\mathrm{nt}$ & $\mathrm{nt}$ \\
CDDP & $25.4 \pm 8.5$ & $18.1 \pm 5.1$ & $5.8 \pm 2.4$ & $39.9 \pm 4.6$ & $21.8 \pm 3.9$ & $32.0 \pm 9.6$ & $>50.0$ & $3.8 \pm 1.5$ \\
OXA & $>50.0$ & $>50.0$ & $>50.0$ & $>50.0$ & $>50.0$ & $>50.0$ & $>50.0$ & $>50.0$ \\
\hline
\end{tabular}

With respect to the results obtained on HOS and MCF7, the complex 2 was tested against next six human cancer cell lines, namely malignant melanoma (G361), cervix carcinoma (HeLa), ovarian carcinoma (A2780), cisplatin-resistant ovarian carcinoma (A2780R), lung carcinoma (A549) and prostate adenocarcinoma ( $\mathrm{LNCaP})$. It has been observed that its in vitro antitumor activity equals $\mathrm{IC}_{50}=17.3 \pm 3.1 \mu \mathrm{M}(\mathrm{G} 361 ; 5.8 \pm 2.4 \mu \mathrm{M}$ for cisplatin, $>50.0 \mu \mathrm{M}$ for oxaliplatin $), \mathrm{IC}_{50}=31.8 \pm 6.2 \mu \mathrm{M}$ $\left(\mathrm{HeLa} ; 39.9 \pm 4.6 \mu \mathrm{M}\right.$ for cisplatin, $>50.0 \mu \mathrm{M}$ for oxaliplatin), $\mathrm{IC}_{50}=19.2 \pm 3.7 \mu \mathrm{M}(\mathrm{A} 2780$; $21.8 \pm 3.9 \mu \mathrm{M}$ for cisplatin, $>50.0 \mu \mathrm{M}$ for oxaliplatin) and $\mathrm{IC}_{50}>50.0 \mu \mathrm{M}(\mathrm{A} 2780 \mathrm{R}, \mathrm{A} 549$ and $\mathrm{LNCaP} ; 32.0 \pm 9.6,>50.0$ and $3.8 \pm 1.5 \mu \mathrm{M}$ for cisplatin, respectively, $>50.0 \mu \mathrm{M}$ for oxaliplatin) cell lines (Table 1, Figure 3). The antitumor activity of 2 against G361, HeLa, A2780, A2780R, A549 and LNCaP can be evaluated as moderate and slightly higher on A2780 and HeLa in comparison with clinically used platinum-based therapeutic cisplatin and on G361, A2780 and HeLa as compared with another platinum-based drug oxaliplatin.

As it is mentioned above, $\mathbf{1}-\mathbf{3}$ follow recently reported [24] analogous oxalato complexes involving different types of 7-azaindole halogeno-derivatives, concretely 3-chloro-7-azaindole (3Claza), 3-iodo7-azaindole (3Iaza) and 5-bromo-7-azaindole (5Braza), which, similarly to $\mathbf{1}$ and $\mathbf{3}$, did not show any effect against both HOS and MCF7 cell lines up to the concentration of 10.0, 25.0, and $0.5 \mu \mathrm{M}$, respectively. Concerning all six platinum(II) oxalato complexes with different 7 -azaindole derivatives together, it can be said that the biological activity, in terms of bioavailability, is strongly affected by 
the position of halogeno-substituent of the 7-azaindole moiety, because the solubility of the complexes with 3Claza, 3Braza and 3Iaza $(10.0-50.0 \mu \mathrm{M})$ is significantly higher than that of the complexes involving the 7-azaindole derivatives substituted in the position 4 (4Claza and 4Braza) or 5 (5Braza), whose solubility did not exceed $1.0 \mu \mathrm{M}$ in the medium used.

Figure 3. The in vitro antitumor activity of the complex 2 and cisplatin (CDDP) on osteosarcoma (HOS), breast adenocarcinoma (MCF7), malignant melanoma (G361), cervix carcinoma (HeLa) and ovarian carcinoma (A2780) human cancer cell lines.

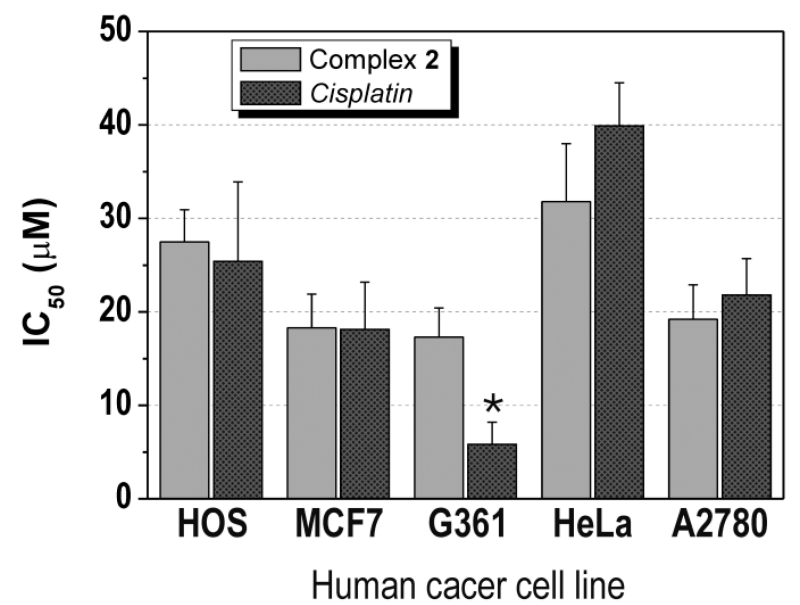

Asterisk $(*)$ symbolizes significant difference $(p<0.05)$ in in vitro antitumour activity of 2 as compared to cisplatin; $\mathrm{nt}=$ not tested.

\section{Experimental Section}

\subsection{Materials and Methods}

Potassium tetrachloridoplatinate(II) $\left(\mathrm{K}_{2}\left[\mathrm{PtCl}_{4}\right]\right)$, potassium oxalate monohydrate $\left(\mathrm{K}_{2}(\mathrm{ox}) \cdot \mathrm{H}_{2} \mathrm{O}\right)$, 4-chloro-7-azaindole (4Claza), 3-bromo-7-azaindole (3Braza), 4-bromo-7-azaindole (4Braza), cisplatin, oxaliplatin, cysteine (cys), reduced glutathione (GSH), guanosine 5'-monophosphate disodium salt (GMP) and solvents were purchased from Sigma-Aldrich Co. (Prague, Czech Republic) and Acros Organics Co. (Pardubice, Czech Republic) and used as received.

General methods: Elemental analysis was performed on a Flash 2000 CHNS Elemental Analyzer (Thermo Scientific, Waltham, MA, USA).

Electrospray ionization mass spectrometry (ESI-MS): Mass spectra were obtained on fresh methanol solutions and after $2 \mathrm{~h}$ and $12 \mathrm{~h}$ by an LCQ Fleet ion trap mass spectrometer using both the positive $(\mathrm{ESI}+)$ negative (ESI-) mode electrospray ionization technique (Thermo Scientific, QualBrowser software, version 2.0.7, Thermo Fischer Scientific, Waltham, MA, USA). The $10 \mu \mathrm{M}$ (final concentration) solution of $\mathbf{2}$ in methanol was mixed together with the same volume of water (hydrolysis studies; presence of methanol ensured the solubility of the studied complex, because carrying out of the experiments in water was prevented by limited solubility of the mentioned complex in water), water solutions of the mixture of GSH $(6 \mu \mathrm{M})$ and cys $(260 \mu \mathrm{M})$ or water solution of GMP. $20 \mu \mathrm{L}$ of the mixtures was analysed by means of flow injection analysis/mass spectrometry (FIA/ESI-MS) in both the positive and negative ionization modes $0 \mathrm{~h}, 2 \mathrm{~h}$ and $12 \mathrm{~h}$ after the preparation. 
NMR spectroscopy: ${ }^{1} \mathrm{H},{ }^{13} \mathrm{C}$ and ${ }^{195} \mathrm{Pt}$ NMR spectra and two dimensional correlation ${ }^{1} \mathrm{H}-{ }^{1} \mathrm{H}$ gs-COSY, ${ }^{1} \mathrm{H}-{ }^{13} \mathrm{C}$ gs-HMQC, ${ }^{1} \mathrm{H}_{-}{ }^{13} \mathrm{C}$ gs-HMBC and ${ }^{1} \mathrm{H}_{-}{ }^{15} \mathrm{~N}$ gs-HMBC experiments (DMF- $d_{7}$ solutions) were performed at $300 \mathrm{~K}$ on a Varian 400 device (Santa Clara, CA, USA) at $400.00 \mathrm{MHz}\left({ }^{1} \mathrm{H}\right), 100.58 \mathrm{MHz}$ $\left({ }^{13} \mathrm{C}\right), 86.00 \mathrm{MHz}\left({ }^{195} \mathrm{Pt}\right)$ and $40.53 \mathrm{MHz}\left({ }^{15} \mathrm{~N}\right)$; gs = gradient selected, COSY = correlation spectroscopy, $\mathrm{HMQC}=$ heteronuclear multiple quantum coherence, $\mathrm{HMBC}=$ heteronuclear multiple bond coherence. ${ }^{1} \mathrm{H}$ and ${ }^{13} \mathrm{C}$ spectra were adjusted against $\mathrm{SiMe}_{4}$, while ${ }^{195} \mathrm{Pt}$ spectra were calibrated against $\mathrm{K}_{2}\left[\mathrm{PtCl}_{6}\right]$ in $\mathrm{D}_{2} \mathrm{O}$ found at $0 \mathrm{ppm} .{ }^{1} \mathrm{H}^{15}{ }^{15}$ gs-HMBC experiments were obtained at natural abundance and calibrated against the residual signals of DMF (8.03 ppm for ${ }^{1} \mathrm{H}, 104.7 \mathrm{ppm}$ for ${ }^{15} \mathrm{~N}$ ). The splitting of proton resonances in the reported ${ }^{1} \mathrm{H}-\mathrm{NMR}$ spectra is defined as $\mathrm{s}=$ singlet, $\mathrm{d}=$ doublet, $\mathrm{t}=$ triplet, $\mathrm{br}$ $=$ broad band, $\mathrm{m}=$ multiplet. The coordination shift $(\Delta \delta ; \mathrm{ppm})$ is calculated as $\Delta \delta=\delta_{\text {complex }}-\delta_{\text {ligand }}$. The stability studies of the DMF- $d_{7}$ and DMF- $d_{7} / \mathrm{H}_{2} \mathrm{O}(9: 1 v / v)$ solutions of 2 was carried out by means of ${ }^{1} \mathrm{H}$ and ${ }^{195} \mathrm{Pt}$ NMR after 1, 2, 3, 4 and 5 days of standing at laboratory temperature.

\subsection{Synthesis of Complexes 1-3}

A solution of $1.0 \mathrm{mmol}$ of 4 Claza (for 1), 3Braza (for 2) or 4 Braza (for 3) in $10 \mathrm{~mL}$ of hot $\left(50{ }^{\circ} \mathrm{C}\right.$ ) ethanol was slowly poured into the solution of $\mathrm{K}_{2}\left[\mathrm{Pt}(\mathrm{ox})_{2}\right] \cdot 2 \mathrm{H}_{2} \mathrm{O}(0.5 \mathrm{mmol})$ in $10 \mathrm{~mL}$ of hot $\left(50{ }^{\circ} \mathrm{C}\right)$ distilled water. The reaction mixtures were stirred at $50{ }^{\circ} \mathrm{C}$ for two days. The products, which formed, were filtered off, washed ( $5 \mathrm{~mL}$ of distilled water and $5 \mathrm{~mL}$ of ethanol) and dried at $40{ }^{\circ} \mathrm{C}$ (Figure 1). The described syntheses followed a procedure reported in our recent works for analogous complexes with different 7-azaindoles [23,24].

Bis(4-chloro-7-azaindole)- $\kappa N 7$ \} (oxalato- $\kappa^{2} O, O^{\prime}$ )platinum(II) $\left(\mathbf{1}, \mathrm{C}_{16} \mathrm{H}_{10} \mathrm{~N}_{4} \mathrm{Cl}_{2} \mathrm{O}_{4} \mathrm{Pt}\right)$ Light grey solid; yield $80 \%$; ${ }^{1} \mathrm{H}-\mathrm{NMR} \quad\left(400.0 \mathrm{MHz}, \mathrm{DMF}-d_{7}\right): \delta / \Delta \delta=13.41 / 1.34$ (br, NH-1), 8.71/0.49 (d, $J=6.4, \mathrm{CH}-6$ ), 7.98/0.30 (d, $J=3.6, \mathrm{CH}-2), 7.37 / 0.17$ (d, $J=6.3, \mathrm{CH}-5), 6.79 / 0.21$ (d, $J=3.6, \mathrm{CH}-3$ ) ppm. ${ }^{13} \mathrm{C}-\mathrm{NMR}\left(100.6 \mathrm{MHz}, \mathrm{DMF}-d_{7}\right): \delta / \Delta \delta=165.9$ (C-11,12), 148.2/-1.6 (C-7a), 146.6/3.0 (CH-6), 138.4/3.8 (C-4), 129.3/1.9 (CH-2), 122.2/3.1 (C-3a), 117.5/1.9 (CH-5), 100.5/2.2 (CH-3) ppm. ${ }^{15} \mathrm{~N}-\mathrm{NMR}\left(40.5 \mathrm{MHZ}, \mathrm{DMF}-d_{7}\right): \delta / \Delta \delta=145.6 / 3.4(\mathrm{NH}-1), 154.6 /-114.6(\mathrm{~N}-7) \mathrm{ppm} .{ }^{195} \mathrm{Pt} \mathrm{NMR}(86.0$ MHz, DMF- $\left.d_{7}\right): \delta=-1770.1$ ppm. ESI MS (30 ev): $m / z=611.1(\mathrm{M}+\mathrm{Na}), 585.9(\mathrm{M}-\mathrm{H}), 434.0$ (M-4Claza-H), 153.1 (4Claza+H), 151.0 (4Claza-H). Anal. Calc.: C, 32.7\%; H, 1.7\%; N, 9.5\%. Found: C, $32.8 \%$; H, $1.6 \%$; N $9.6 \%$.

Bis(3-bromo-7-azaindole)- $\kappa N 7$ \} (oxalato- $\kappa^{2} O, O^{\prime}$ )platinum(II) (2, $\left.\mathrm{C}_{16} \mathrm{H}_{10} \mathrm{~N}_{4} \mathrm{Br}_{2} \mathrm{O}_{4} \mathrm{Pt}\right)$ Light grey solid; yield 75\%; ${ }^{1} \mathrm{H}-\mathrm{NMR}\left(400.0 \mathrm{MHz}, \mathrm{DMF}-d_{7}\right): \delta / \Delta \delta=13.49 / 1.32$ (br, NH-1), 8.82/0.48 (d, $J=5.7, \mathrm{CH}-6$ ), 8.11/0.23 (d, $J=8.0, \mathrm{CH}-4), 8.09 / 0.31$ (s, CH-2), 7.31/0.10 (m, CH-5) ppm. ${ }^{13} \mathrm{C}-\mathrm{NMR}(100.6 \mathrm{MHz}$, DMF- $\left.d_{7}\right): \delta / \Delta \delta=166.0$ (C-11,12), 147.5/3.2 (CH-6), 147.0/-0.9 (C-7a), 130.6/4.0 (CH-4), 128.0/2.1 $(\mathrm{CH}-2), 122.6 / 3.3$ (C-3a), 118.0/1.4 (CH-5), 89.3/1.6 (C-3) ppm. ${ }^{15} \mathrm{~N}-\mathrm{NMR}\left(40.5 \mathrm{MHZ}, \mathrm{DMF}-d_{7}\right)$ : $\delta / \Delta \delta=143.5 / 2.5(\mathrm{NH}-1), 159.4 /-115.1(\mathrm{~N}-7) .{ }^{195} \mathrm{Pt} \mathrm{NMR}\left(86.0 \mathrm{MHz}, \mathrm{DMF}-d_{7}\right): \delta=-1783.5 \mathrm{ppm}$. ESI MS (30 ev): $m / z=678.9(\mathrm{M}+\mathrm{H}), 676.0(\mathrm{M}-\mathrm{H}), 478.1(\mathrm{M}-3$ Braza-H), $197.1(3$ Braza+H), 195.1 (3Braza-H). Anal. Calc.: C, 28.4\%; H, 1.5\%; N, 8.3\%. Found: C, 28.4\%; H, 1.5\%; N, 8.3\%.

Bis(4-bromo-7-azaindole)- $\kappa N 7$ \} (oxalato- $\kappa^{2} O, O^{\prime}$ )platinum(II) (3, $\left.\mathrm{C}_{16} \mathrm{H}_{10} \mathrm{~N}_{4} \mathrm{Br}_{2} \mathrm{O}_{4} \mathrm{Pt}\right)$ Light grey solid; yield $80 \%$; ${ }^{1} \mathrm{H}-\mathrm{NMR}\left(400.0 \mathrm{MHz}, \mathrm{DMF}-d_{7}\right): \delta / \Delta \delta=13.40 / 1.31$ (br, NH-1), 8.60/0.47 (d, $J=6.3, \mathrm{CH}-6$ ), 
8.00/0.30 (d, $J=3.5, \mathrm{CH}-2), 7.51 / 0.16(\mathrm{~d}, J=6.2, \mathrm{CH}-5), 6.72 / 0.21(\mathrm{~d}, J=3.5, \mathrm{CH}-3) \mathrm{ppm} .{ }^{13} \mathrm{C}-\mathrm{NMR}$ (100.6 MHz, DMF- $\left.d_{7}\right): \delta / \Delta \delta=165.9$ (C-11,12), 147.3/-1.6 (C-7a), 146.3/2.9 (CH-6), 129.4/1.9 (CH-2), 128.0/4.1 (C-3a), 124.6/3.2 (C-4), 120.6/1.8 (CH-5), 102.1/2.2 (CH-3) ppm. ${ }^{15} \mathrm{~N}-\mathrm{NMR}$ (40.5 MHZ, DMF- $\left.d_{7}\right): \quad \delta / \Delta \delta=145.5 / 3.1 \quad(\mathrm{NH}-1), \quad 155.4 /-114.0 \quad(\mathrm{~N}-7) .{ }^{195} \mathrm{Pt}$ NMR $\left(86.0 \mathrm{MHz}, \mathrm{DMF}-d_{7}\right):$ $\delta=-1772.5$ ppm. ESI MS (30 ev): $m / z=679.0(\mathrm{M}+\mathrm{H}), 676.0(\mathrm{M}-\mathrm{H}), 478.1(\mathrm{M}-4$ Braza-H), 197.1 (4Braza+H), 195.1 (4Braza-H). Anal. Calc.: C, 28.4\%; H, 1.5\%; N, 8.3\%. Found: C, 28.3\%; H, 1.5\%; N, $8.4 \%$.

\subsection{In Vitro Cytotoxicity Testing}

Breast adenocarcinoma (MCF7; ECACC No. 86012803), osteosarcoma (HOS; ECACC No. 87070202), malignant melanoma (G361; ECACC No. 88030401), cervix epitheloid carcinoma (HeLa; ECACC No. 93021013), A2780 ovarian carcinoma (ECACC No. 93112519), A2780R cisplatin-resistant ovarian carcinoma (ECACC No.93112517), lung carcinoma (A549; ECACC No.86012804) and prostate adenocarcinoma (LNCaP; ECACC No. 89110211) cancer cell lines were purchased from European Collection of Cell Cultures (ECACC; Prague, Czech Republic).

In vitro cytotoxicity was determined by an MTT assay against MCF7 (the complexes 1-3), HOS (1-3), G361 (2), HeLa (2), A2780 (2), A2780R (2), A549 (2) and LNCaP (2) human cancer cell lines. The cells were maintained in a humidified incubator $\left(37^{\circ} \mathrm{C}, 5 \% \mathrm{CO}_{2}\right)$. The cells were treated with 1-3 or standards (cisplatin, oxaliplatin) at the $0.01,0.1,1.0,5.0,25.0$ and $50 \mu \mathrm{M}$ concentrations for $24 \mathrm{~h}$, using multi-well culture plates of 96 wells. In parallel, the cells were treated with vehicle (DMF; $0.1 \%, v / v$ ) and Triton X-100 $(1 \%, v / v)$ to assess the minimal (i.e., positive control) and maximal (i.e., negative control) cell damage, respectively. The MTT assay was measured spectrophotometrically at $540 \mathrm{~nm}$ (TECAN, Schoeller Instruments LLC). The data were expressed as the percentage of viability, when $100 \%$ and $0 \%$ represent the treatments with DMF and Triton X-100, respectively. The cytotoxicity data from the cancer cell lines were acquired from three independent experiments (conducted in triplicate) using cells from different passages. The $\mathrm{IC}_{50}$ values $(\mu \mathrm{M})$ were calculated from viability curves. The results are presented as arithmetic mean $\pm \mathrm{SD}$.

The significance of the differences between the results was assessed by the ANOVA analysis, followed by Tukey's post-hoc test for multiple comparisons, with $p<0.05$ considered to be significant (QC Expert 3.2, Statistical software, TriloByte Ltd., Pardubice, Czech Republic).

\section{Conclusions}

This work describes three new platinum(II) oxalato complexes [Pt(ox)(naza) $)_{2}(\mathbf{1}-\mathbf{3})$ and evaluates their in vitro cytotoxicity on the selected human cancer cell lines. The testing revealed the complex 2 (involving 3Braza) as in vitro antitumor active against HOS, MCF7, G361, HeLa and A2780 with $\mathrm{IC}_{50} \approx 17-32 \mu \mathrm{M}$. Because the complex 2 differs from 1 (involving 3Claza) and 3 (involving 4Braza) in the nature or position of the 7-azaindole moiety substituent, it can be concluded that 3 Braza represents a very perspective $N$-donor ligand, which could be used as a carrier ligand involved into platinum(II) complexes with different leaving group than oxalato one. 


\section{Acknowledgments}

The authors thank the Czech Science Foundation (GAČR P207/11/0841), Operational Program Research and Development for Innovations-European Regional Development Fund (CZ.1.05/2.1.00/03.0058) of the Ministry of Education, Youth and Sports of the Czech Republic, and Palacký University in Olomouc (PrF_2013_015 and PrF_2014_009). The authors also thank Bohuslav Drahoš and Ján Vančo for help with ESI-MS experiments, Radka Křikavová for assistance with NMR experiments, and Alexandr Popa for collaboration on the syntheses.

\section{Author Contributions}

Conceived and designed the experiments: PŠ, ZT, IP, ZD. Performed the experiments: PŠ, ZT, IP, ZD. Analyzed the data: PŠ, ZT, IP, ZD. Wrote the paper: PŠ, ZT.

\section{Conflicts of Interest}

The authors declare no conflict of interest.

\section{References}

1. Kelland, L. The resurgence of platinum-based cancer chemotherapy. Nat. Rev. Cancer 2007, 7, 573-584.

2. Kelland, L.R.; Farrell, N.P. Platinum Based Drugs in Cancer Therapy; Humana Press: Totowa, NJ, USA, 2000.

3. Gielen, M.; Tiekink, E.R.T. Metallotherapeutic Drugs and Metal-Based Diagnostic Agents; John Wiley \& Sons, Ltd.: Chichester, UK, 2005.

4. Harrap, K.R. Preclinical studies identifying carboplatin as a viable cisplatin alternative. Cancer Treat. Rev. 1985, 12, 21-33.

5. Akaza, H.; Togashi, M.; Nishio, Y.; Miki, T.; Kotake, T.; Matsumura, Y. Yoshida, O.; Aso, Y. Phase II study of cis-diammine(glycolato)platinum, 254-S, in patients with advanced germ-cell testicular cancer, prostatic cancer, and transitional-cell carcinoma of the urinary tract. Cancer Chemoth. Pharm. 1992, 31, 187-192.

6. McKeage, M.J. Lobaplatin: A new antitumour platinum drug. Expert Opin. Inv. Drugs 2001, 10, 119-128.

7. Kim, D.K.; Kim, G.; Gam, J.; Cho, Y.B.; Kim, H.T.; Tai, J.H.; Kim, K.H.; Hong, W.S.; Park, J.G. Synthesis and antitumor activity of a series of [2-substituted-4,5-bis(aminomethyl)-1,3-dioxolane] platinum(II) complexes. J. Med. Chem. 1994, 37, 1471-1485.

8. Kelland, L.R.; Abel, G.; McKeage, M.J.; Jones, M.; Goddard, P.M.; Valenti, M.; Murrer, B.A.; Harrap, K.R. Preclinical antitumor evaluation of bis-acetato-ammine-dichloro-cyclohexylamine platinum(IV): An orally active platinum drug. Cancer Res. 1993, 53, 2581-2583.

9. Dragovich, T.; Mendelson, D.; Kurtin, S.; Richardson, K.; Von Hoff, D.; Hoos, A. A Phase 2 trial of the liposomal DACH platinum L-NDDP in patients with therapy-refractory advanced colorectal cancer. Cancer Chemoth. Pharm. 2006, 58, 759-764. 
10. Kidani, Y.; Inagaki, K.; Iigo, M.; Hoshi, A.; Kuretani, K. Antitumor activity of 1,2diaminocyclohexaneplatinum complexes against Sarcoma-180 ascites form. J. Med. Chem. 1978, $21,1315-1318$.

11. Zhang, J.C.; Liu, D.D.; Li, Y.P.; Sun, J.; Wang, L.W.; Zang, A.M. Status of Non-classical mononuclear platinum anticancer drug development. Mini-Rev. Med. Chem. 2009, 9, 1357-1366.

12. Butler, J.S.; Sadler, P.J. Targeted delivery of platinum-based anticancer complexes. Curr. Opin. Chem. Biol. 2013, 17, 175-188.

13. Harper, B.W.; Krause-Heuer, A.M.; Grant, M.P.; Manohar, M.; Garbutcheon-Singh, K.B.; Aldrich-Wright, J.R. Advances in platinum chemotherapeutics. Chem. Eur. J. 2010, 16, 7064-7077.

14. Holford, J.; Sharp, S.Y.; Murrer, B.A.; Abrams, M.; Kelland, L.R. In vitro circumvention of cisplatin resistance by the novel sterically hindered platinum complex AMD473. Br. J. Cancer 1998, 77, 366-373.

15. Stein, A.; Arnold, D. Oxaliplatin: A review of approved uses. Expert Opin. Pharmacother. 2012, $13,125-137$.

16. Cleare, M.J. Transition metal complexes in cancer chemotherapy. Coord. Chem. Rev. 1974, 12, 349-405.

17. Štarha, P.; Trávníček, Z.; Popa, I. Platinum(II) oxalato complexes with adenine-based carrier ligands showing significant in vitro antitumor activity. J. Inorg. Biochem. 2010, 104, 639-647.

18. Trávníček, Z.; Štarha, P.; Popa, I.; Vrzal, R.; Dvořák, Z. Roscovitine-based CDK inhibitors acting as N-donor ligands in the platinum(II) oxalato complexes: Preparation, characterization and in vitro cytotoxicity. Eur. J. Med. Chem. 2010, 45, 4609-4614.

19. Vrzal, R.; Štarha, P.; Dvořák, Z.; Trávníček, Z. Evaluation of in vitro cytotoxicity and hepatotoxicity of platinum(II) and palladium(II) oxalato complexes with adenine derivatives as carrier ligands. J. Inorg. Biochem. 2010, 104, 1130-1132.

20. Utku, S.; Topal, M.; Dögen, A.; Serin, M.S. Synthesis, characterization, antibacterial and antifungal evaluation of some new platinum(II) complexes of 2-phenylbenzimidazole ligands. Tur. J. Chem. 2010, 34, 427-436.

21. Silva, H.; Barra, C.V.; Rocha, F.V.; Frézard, F.; Lopes, M.T.P.; Fontes, A.P.S. Novel platinum(II) complexes of long chain aliphatic diamine ligands with oxalato as the leaving group. Comparative cytotoxic activity relative to chloride precursors. J. Braz. Chem. Soc. 2010, 21, 1961-1967.

22. Sun, Y.; Yin, R.; Gou, S.; Zhao, J. Antitumor platinum(II) complexes of N-monoalkyl-1R, $2 R$-diaminocyclohexane derivatives with alkyl groups as hindrance. J. Inorg. Biochem. 2012, 112, $68-76$.

23. Štarha, P.; Marek, J.; Trávníček, Z. Cisplatin and oxaliplatin derivatives involving 7-azaindole: Structural characterisations. Polyhedron 2012, 33, 404-409.

24. Štarha, P.; Trávníček, Z.; Popa, A.; Popa, I.; Muchová, T.; Brabec, V. How to modify 7-azaindole to form cytotoxic $\mathrm{Pt}(\mathrm{II})$ complexes: Highly in vitro anticancer effective cisplatin derivatives involving halogeno-substituted 7-azaindole. J. Inorg. Biochem. 2012, 105, 57-63.

25. Štarha, P.; Trávníček, Z.; Popa, I. Synthesis, characterization and in vitro cytotoxicity of the first palladium(II) oxalato complexes involving adenine-based ligands. J. Inorg. Biochem. 2009, 103, 978-988. 
26. Štarha, P.; Popa, I.; Trávníček, Z. Palladium(II) oxalato complexes involving N6-(benzyl)-9isopropyladenine-based N-donor carrier ligands: Synthesis, general properties, ${ }^{1} \mathrm{H},{ }^{13} \mathrm{C}$ and ${ }^{15} \mathrm{~N}\left\{{ }^{1} \mathrm{H}\right\}$ NMR characterization and in vitro cytotoxicity. Inorg. Chim. Acta 2010, 363, 1469-1478.

27. Siddik, Z.H. Cisplatin: Mode of cytotoxic action and molecular basis of resistance. Oncogene 2003, 22, 7265-7279.

28. Berners-Price, S.J.; Ronconi, L.; Sadler, P.J. Insights into the mechanism of action of platinum anticancer drugs from multinuclear NMR spectroscopy. Prog. Nucl. Mag. Res. Sp. 2006, 49, 65-98.

29. Mistry, P.; Kelland, L.R.; Abel, G.; Sidhar, S.; Harrap, K.R. The relationships between glutathione, glutathione-S-transferase and cytotoxicity of platinum drugs and melphalan in eight human ovarian carcinoma cell lines. Br. J. Cancer 1991, 64, 215-220.

30. Luo, F.R.; Yen, T.Y.; Wyrick, S.D.; Chaney, S.G. High-performance liquid chromatographic separation of the biotransformation products of oxaliplatin. J. Chromatogr. B 1999, 724, 345-356.

31. Ravera, M.; Bagni, G.; Mascini, M.; Dabrowiak, J.C.; Osella, D. The activation of platinum(II) antiproliferative drugs in carbonate medium evaluated by means of a DNA-biosensor. J. Inorg. Biochem. 2007, 101, 1023-1027.

32. Kim, Y.S.; Shin, S.; Cheong, M.; Hah, S.S. Mechanistic Insights into in vitro DNA Adduction of Oxaliplatin. Bull. Korean Chem. Soc. 2010, 31, 2043-2046.

33. Reedijk, J. Increased understanding of platinum anticancer chemistry. Pure Appl. Chem. 2011, 83, 1709-1719.

Sample Availability: Samples of the compounds 1-3 are available from the authors.

(C) 2014 by the authors; licensee MDPI, Basel, Switzerland. This article is an open access article distributed under the terms and conditions of the Creative Commons Attribution license (http://creativecommons.org/licenses/by/3.0/). 